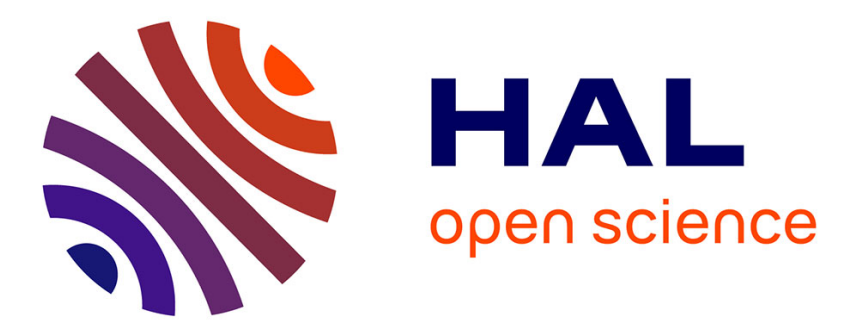

\title{
Developing a Green Product-Based in an Open Innovation Environment. Case Study: Electrical Vehicle
}

Ricardo Santos, António Abreu, Vitor Anes

\section{To cite this version:}

Ricardo Santos, António Abreu, Vitor Anes. Developing a Green Product-Based in an Open Innovation Environment. Case Study: Electrical Vehicle. 20th Working Conference on Virtual Enterprises (PRO-VE), Sep 2019, Turin, Italy. pp.115-127, 10.1007/978-3-030-28464-0_11 . hal-02478794

\section{HAL Id: hal-02478794 \\ https://hal.inria.fr/hal-02478794}

Submitted on 14 Feb 2020

HAL is a multi-disciplinary open access archive for the deposit and dissemination of scientific research documents, whether they are published or not. The documents may come from teaching and research institutions in France or abroad, or from public or private research centers.
L'archive ouverte pluridisciplinaire HAL, est destinée au dépôt et à la diffusion de documents scientifiques de niveau recherche, publiés ou non, émanant des établissements d'enseignement et de recherche français ou étrangers, des laboratoires publics ou privés. 


\title{
Developing a Green Product-based in an Open Innovation Environment. Case Study: Electrical Vehicle
}

\author{
Ricardo Santos ${ }^{13}$ [0000-0001-5703-8139], Antonio Abreu ${ }^{23[0000-0001-8839-5606] ~}$ \\ Vitor Anes 3 [0000-0002-8526-398X] \\ ${ }^{1}$ GOVCOPP - University of Aveiro, Portugal \\ ricardosimoessantos84@ua.pt \\ ${ }^{2}$ CTS Uninova, Faculdade de Ciências e Tecnologia, Universidade Nova de Lisboa, Portugal \\ ${ }^{3}$ ISEL- Instituto Superior de Engenharia de Lisboa, Instituto Politécnico de Lisboa, Portugal
}

\begin{abstract}
In order to respond to new market challenges, companies have attempted to develop open innovation processes with other organizations such as research centers and higher-education institutions. However, it is also frequently mentioned by several companies that the lack of models that support open innovation in a sustainable way, involving higher-education institutions or research centers and companies in the context of a collaborative environment, is an obstacle for a wider acceptance of this way of promoting innovation processes. Starting with some discussion about innovation models in a collaborative context, this paper discusses the developed of an electric vehicle based on an open-innovation approach among several companies and a Portuguese university.
\end{abstract}

Keywords: Business Sustainability, Open Innovation, New Product Development,

Collaborative Networks

\section{Introduction}

Currently, there are even more electric vehicles in the market, mainly due to the competitiveness levels achieved, as well as the increasingly affordable acquisition costs, coupled in turn, with a greater autonomy and energy efficiency, placing therefore this vehicle, in a position, even more closed by the internal combustion vehicles.

The increasingly need of competitiveness by the companies, as well as the need to expand their competences, know-how and create substantial competitive advantage, lead them, to form alliances, partnerships and collaborative networks with outsiders in order to overcome potential capacity limitations, knowledge gaps, promoting therefore, innovative and dynamic relationships, useful for future projects for instance ([1-3]).

Open Innovation (OI), allows to distribute innovation across organizational boundaries, by using collaborative networks and a wide range of external actors and sources to help them to achieve and sustain innovation and competitiveness as well [4-5]. 
However, there seems to be a lack of evidence of successfully applied models, to support the way that the organizations, uses OI, to develop new products or services in the collaborative network's context, especially regarding the electrical vehicle's development.

In this work it's presented an Open Innovation model to support the decision makers of the collaborative network, by planning the development of a green product such an electric vehicle in an open innovation context.

The proposed approach combines collaborative networks, regarding different partnerships (suppliers, government, university, etc.) with a model of innovation management, regarding New Products Development (NPD) concept, in order to accelerate the development of an electrical vehicle, used as a case study here.

Evidences of perceived benefits in this case study, and regarding OI context, will also be presented in this work.

Therefore, and based on what was referred before, the research question is:

How to support the green product development in an open innovation context?

\section{Literature Review}

Various literature streams are synthetized here, in order to highlight the multidisciplinary approaches regarding open innovation (OI), including OI models.

The OI, can be defined as "the use of purposive inflows and outflows of knowledge to accelerate internal innovation, and expand the markets for external use of innovation, respectively" ([7]).

On the center of this definition is the triangular relationship among outflow (insideout), inflow (outside-in) and coupled (both directions) open innovation process ([8]). This concept has received wide acceptance on literature ([9]), as well as some criticism, by some authors like [10].

Authors, like [12], defines OI as "a model using a wide range of external actors and sources to help them to achieve and sustain innovation".

OI is also based on collaborative relationships-organizational alliances and partnerships ([13]) who are willing to work together by sharing ideas, know-how, experiences and knowledge to generate value, by achieving innovative outcomes ([14]).

In line with this concept, authors such as [15] perceive three levels of collaborative innovation, namely: management of interorganizational collaboration process, management of the overall innovation process and creation of a new collaborative knowledge.

To expand their competences, their know-how and achieve substantial competitive advantage, organizations share the need to form alliances, partnerships and collaborative networks with outsiders to overcome potential capacity limitations, knowledge gaps, develop the ability to jointly work into new projects and promote innovative and dynamic relationships ([1]).

There are several open innovation models that can be found on literature [16-17].

One of the OI models most used, is the InnoCentive Model ([10]). Created in 2001, InnoCentive is a model of OI, supported in a web platform that bears the same name ([18]) This model consists of six steps that begins with the identification of problems and ideas, the formulation of a challenge, the specification of intellectual property 
agreements, the publication of the challenge, the evaluation of solutions and an award to finalize with the transfer of intellectual property [18-19].

Other model found on literature, more recent and widely used, is created by Procter \& Gamble P \& G, which is defined as "Connect + Develop"([17]).

This model works in both directions inwards and outward, and ranges from registered trademarks to packaging, from marketing models to engineering, and from commercial services to design ([20]).

The chain-linked model (CLM), developed by Kline and Rosenberg in 1985 ([19]) is an attempt to describe complexities in the innovation process.

This model is based on a concept called "systemism" [20], which considers innovation as a system. Systemism, allows the possibility to imagine different scenarios; high versus low research intensity innovation, routine versus breakthrough innovation, methodic versus empirical innovation, local versus global multinational level innovation, making CLM an important innovation model widely used today [17].

Although, the existence of an academic consensus, regarding the value of this model ([17][21]), some authors propose that such model, can be improved to be more contextualized with other contexts, such as open innovation ([21]).

\section{Proposed Open Innovation Model}

The present open innovation model, proposed here, was designed with the aim to serve companies of any size and business, in the transition to an Open Innovation (OI) context.

The purpose of this approach is to contribute with a tool, to support the innovation management and the information associated.

The proposed model, was based on four assumptions, as follows:

- Generalize the classical and very influential model of chain linking from Kline and Rosenberg model ([19]);

- Accommodate the concepts of the $4^{\text {th }}$ Edition of the Oslo Manual ([22]);

- Consider innovation in both industry assets (tangible and intangible) and regarding low-tech companies as well as high-tech ones;

- Innovation results from a chain of interactions between the knowledge from OI's network and the organizations, regarding its external environment;

The proposed model, besides incorporating the assumptions referred above, also intends to structure the process of developing a product /service in a collaborative context, which is supported by a set of knowledge, necessary for its development.

This type of knowledge, needed to reach product/service innovation, is shared with a set of Open Innovation Network (OIN) partners (Pn), which makes the collaboration network, necessary for the development of the product / service in question.

In general, the model can be divided into four different groups of components; Stages of product development (Sn), Interfaces (In), Knowledge Interface groups (KIn) and Process groups (Pr).

These components, can be briefly described, as follows: 
- Stages of product development (Sn) - Consists in a set of monitor indicators, regarding the product/service development, to support the project management;

- Interfaces (In) - Divided into 3 groups, works as channels in which the transfer of knowledge, takes place between the OI's network and the external environment $(\mathrm{EE})$ of the open innovation network, through the interaction between the different partners (Pn) and the corresponding External Collaborators (ECn).

For each interface, are assigned a set of Partners $(\mathrm{Pn})$, which are responsible to establish and control the interactions between Pn and ECn;

- Knowledge interface groups (KIn) - The knowledge changed between Pn and ECn, are organized into 3 types of knowledge (Kin), regarding the correspondent interface (In) (see Table 1). The mechanism of such transfer, is exemplified on Fig.1;

- Process groups (Pr) - Is where the innovations will be applied to develop the product and it results from the transfer and development of different knowledge types (Kn), occurred between the collaborative network partners (Pn), and also between Pn and the External Collaborators (ECn), i.e. from the outside of OI's network (Fig.1).

On Fig.1, are presented the four components referred before.

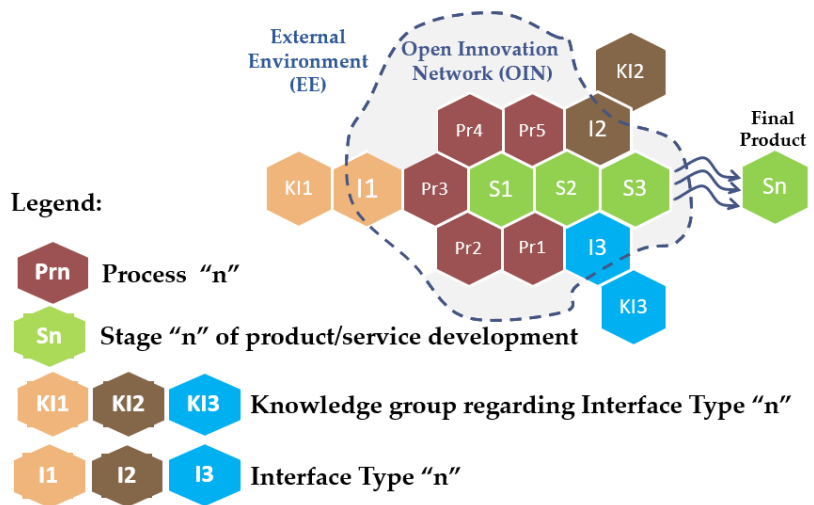

Fig. 1. Model components

Based on what was referred before, and through Fig.1, the model's components, can better described, as it follows:

- KI1 - Existing market knowledge (needs preferences values)

- KI2 - Existing Organizational Knowledge

- KI3 -Existing scientific and technological knowledge

- Pr1 - Potential Market Assessment, Economic Viability Assessment, Selection of ideas Projects 
- Pr2 - Invention, Basic Sketches, Service Design

- $\operatorname{Pr} 3$ - Detailed Drawing

- Pr4 - Redesign Demonstration or Test and Production

- Pr5 - Commercialization or Implementation

- I1- Technology watch/Technology forecast

- I2- Market research

- I3- Knowledge research

In general terms, the innovation process usually starts from a potential market perspective. The activities, regarding interfaces I1, I2 and I3, allows the emergence of ideas to satisfy new market needs, not only by improving products or processes, but also by improving the open innovations' organization to better market the products and reach consumers $(\operatorname{Pr} 1)$.

The ideas, with technological and economic viability, are then selected and give rise to innovation. The invention, product design or service design, are the first step of the project $(\operatorname{Pr} 2)$, followed by the detailed design $(\operatorname{Pr} 3)$, in order to better specify the product/service.

After the Redesign Demonstration or Test and Production process group (Pr4), the process of innovation continues, until the commercialization or implementation of its final result is achieved, which can be related to a product, process, marketing or even organizational $(\operatorname{Pr} 4)$.

Interactions may occur between the different processes of the chain, since that the innovation does not follow a linear path.

The knowledge regarding each process (KnPrn), needed to develop innovation projects, may be internally available through the different partners (Pn) of the open innovation network, or be obtained abroad through the External Environment (EE) between Pn and the EE's External Collaborators (ECn).

Regarding the knowledge transfer mechanisms, there are 2 types used in this model. In Fig.2, are presented two examples of how these two types of mechanisms occur.

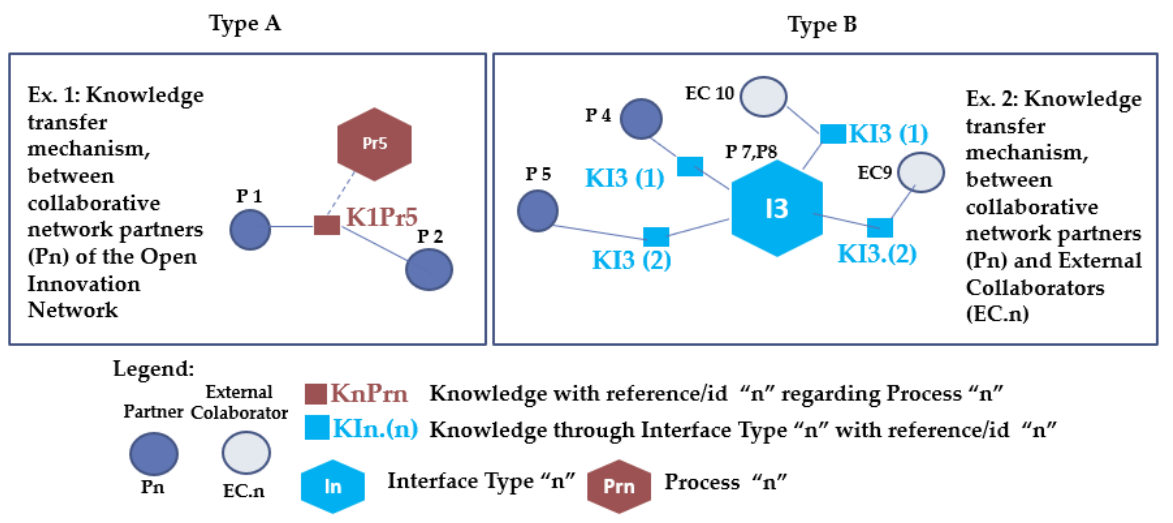

Fig. 2. The two types of knowledge's transferred mechanisms used (Examples): A-Between Partners , B- Between Partners (Pn) and External Collaborators (EC.n) 
Through Fig.2, and more specifically, through Example 1 (Ex.1), it can be seen an interaction between 2 open innovation's partners, where the knowledge (K1Pr5), related to Process 5 (Pr5), is transferred between P1 and P2.

In the same figure, and regarding Example 2 (Ex.2), there are some differences, since between each knowledge transfer, there is an interface (In), which controls and monitories, each knowledge transfer, regarding to group $\mathrm{Kn}$, which is related to In. This control occurs in order to manage the knowledge transfer, according to the project needs, promoting therefore efficiency.

On Ex.2, there are two interactions, that can be observed; one, between P5 and EC.9 (KI3(2)) and the other one, between P4 and EC.10 (KI3(1)).

In more detail, and based on Fig. 1, the model assumes the following components, listed on Table 1:

Table 1. Components, regarding the proposed model

\begin{tabular}{|c|c|c|}
\hline Knowledge Interface (KIn) & $\mathbf{K I n}(\mathbf{n})$ & $\begin{array}{c}\text { Actors } \\
\text { Involved }\end{array}$ \\
\hline $\begin{array}{l}\text { KI1 - Existing market knowledge (needs preferences val- } \\
\text { ues) }\end{array}$ & $\mathrm{KI} 1(1) . . \mathrm{KI} 1(\mathrm{n})$ & $\begin{array}{c}\mathrm{P} 1 . . \mathrm{Pn} \mid \\
\mathrm{EC} 1 . . \mathrm{ECn}\end{array}$ \\
\hline KI2 - Existing Organizational Knowledge & $\mathrm{KI} 2(1) . . \mathrm{KI} 2(\mathrm{n})$ & $\begin{array}{c}\mathrm{P} 1 . . \mathrm{Pn} \mid \\
\mathrm{EC} 1 . . \mathrm{ECn}\end{array}$ \\
\hline KI3 -Existing scientific and technological knowledge & $\mathrm{KI} 3(1) . . \mathrm{KI} 3(\mathrm{n})$ & $\begin{array}{c}\mathrm{P} 1 . . \mathrm{Pn} \mid \\
\mathrm{EC} 1 . . \mathrm{ECn}\end{array}$ \\
\hline Process (Prn) & KnPrn & $\begin{array}{c}\text { Actors } \\
\text { Involved }\end{array}$ \\
\hline $\begin{array}{l}\text { Pr1 - Potential Market Assessment, Economic Viability } \\
\text { Assessment, Selection of ideas Projects }\end{array}$ & $\mathrm{K} 1 \operatorname{Pr} 1 . . \mathrm{KnPr} 1$ & $\mathrm{P} 1, . ., \mathrm{Pn}$ \\
\hline Pr2 - Invention, Basic Sketches, Service Design & $\mathrm{K} 1 \mathrm{Pr} 2 . . \mathrm{KnPr} 2$ & $\mathrm{P} 1, \ldots, \mathrm{Pn}$ \\
\hline Pr3 - Detailed Drawing & K1Pr3..KnPr3 & $\mathrm{P} 1, \ldots, \mathrm{Pn}$ \\
\hline Pr4 - Redesign Demonstration or Test and Production & $\mathrm{K} 1 \mathrm{Pr} 4 . . \mathrm{KnPr} 4$ & $\mathrm{P} 1, \ldots, \mathrm{Pn}$ \\
\hline Pr5 - Commercialization or Implementation & $\mathrm{K} 1 \mathrm{Pr} 5 . . \mathrm{KnPr} 5$ & $\mathrm{P} 1, \ldots, \mathrm{Pn}$ \\
\hline
\end{tabular}

Table 1 allows to assign, each knowledge to be transferred, to a set of actors, involved in the correspondent process. The same, can be preform through Table 2, and regarding each models' interface (I1, I2, I3), where a set of partners, can assign the task (isolated or in group) of managing each interface, as innovation managers.

Table 2. Assignment of Innovation Managers

\begin{tabular}{|l|c|}
\hline \multicolumn{1}{|c|}{ Interfaces (In) } & Assignment of Innovation Managers \\
\hline I1- Technology watch/Technology forecast & $\mathrm{P} 1, \ldots, \mathrm{Pn}$ \\
\hline I2- Market research & $\mathrm{P} 1, . ., \mathrm{Pn}$ \\
\hline I3- Knowledge research & $\mathrm{P} 1, ., \mathrm{Pn}$ \\
\hline
\end{tabular}

Both tables allows to gain control over the process of product/service development, not only between the Partners (Pn) of Open Innovation Network (OIN), but also between Partners (Pn) from OIN and the External Collaborators (ECn), from the External Environment (EE), by identifying the actors/organizations, involved on each knowledge transfer. 
Based on what was referred before, the model can be therefore integrated in an open innovation context (Fig.3).

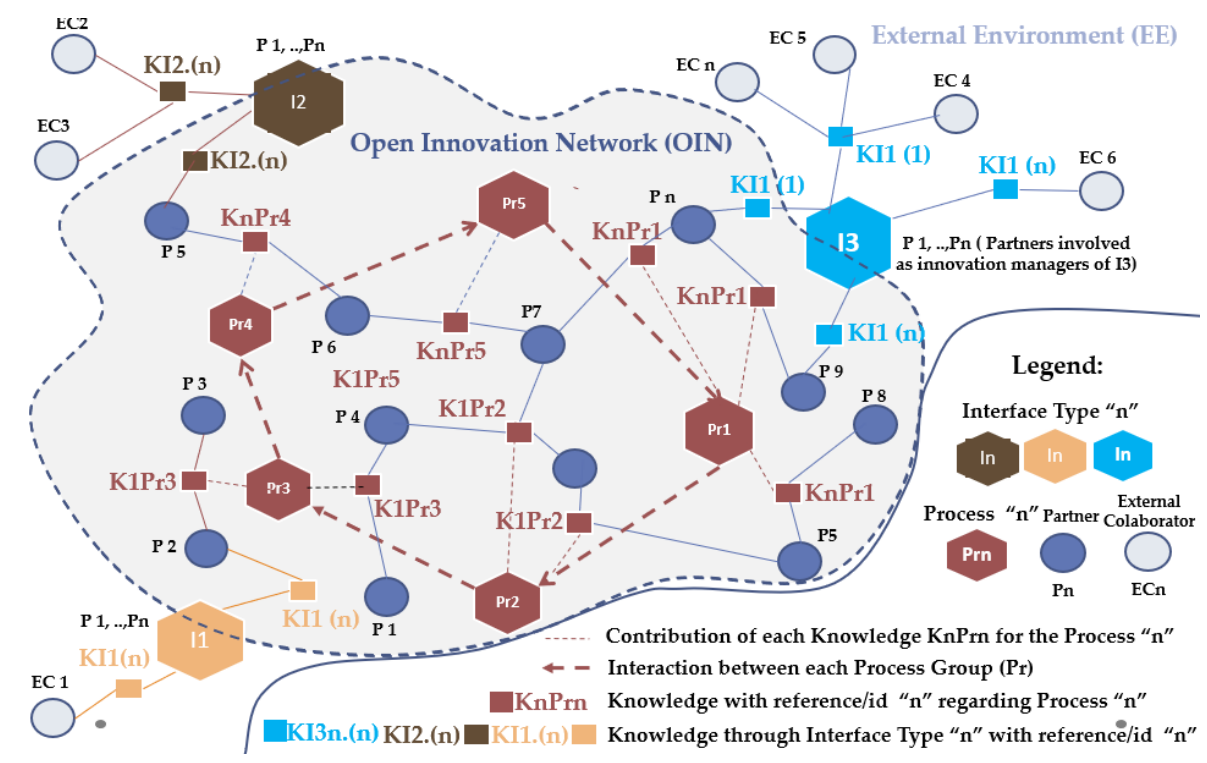

Fig. 3. Proposed model, integrated in open innovation context

Based on what was referred before, The knowledge required and not obtainable by the external collaborators (ECn), will have to be developed and/or transferred, between the Partners (Pn), of the open innovation network.

According to Fig.3, each knowledge transferred (KnPrn) between the Partners (Pn), is a contribution to the Process Group (Prn), which is one of the 5 Process Groups, that composes the linked chain, necessary to develop the product or service, which follows a sequence order. This last concept is based on the work of Kline and Rosenberg [18].

The whole development product/service's process is composed by a set of Process Groups, that composes the chain, namely: $\operatorname{Pr} 1, \operatorname{Pr} 2, \operatorname{Pr} 3, \operatorname{Pr} 4$ and ending in $\operatorname{Pr} 5$.

For product/service's continues improving, this chain can continue to Process Group 1 (Pr1), from Pr5 directly, until the product/service objectives are accomplished.

The knowledge required and obtainable by the external collaborators $(\mathrm{ECn})$, will have to be transferred between the Partners (Pn) and the correspondent External Collaborators (EC.n) involved in the process.

The knowledge to be transferred on this context (Kin.(n)), will be transferred from the respective Interface (In), which will be managed by the Partners (Pn) of the network (isolated or in group) assigned for his function.

Regarding the three interfaces referred above, they don't have to exist simultaneously, and they don't have to constitute disjoint entities as well.

In this sense, the product development process, occurs in a collaboration context, by incorporating the different innovations, resulted from the knowledge transferred, 
associated within the various network partners and external collaborators as well, resulting thus, into a final product/service.

\section{Application to a Case Study: Electric Vehicle}

A Portuguese company of electric vehicles, intended to manufacture an electric passenger vehicle ( 2 seats), energy efficient, safer, and with a greater autonomy, in order to be available in the market segment of two-seat green passenger vehicles.

The insufficient know-how for its production, have leaded the company to produce the vehicle in collaboration with several entities, including industries, universities, Research \& Development (R\&D) centers, and consultancy companies (Fig.4).

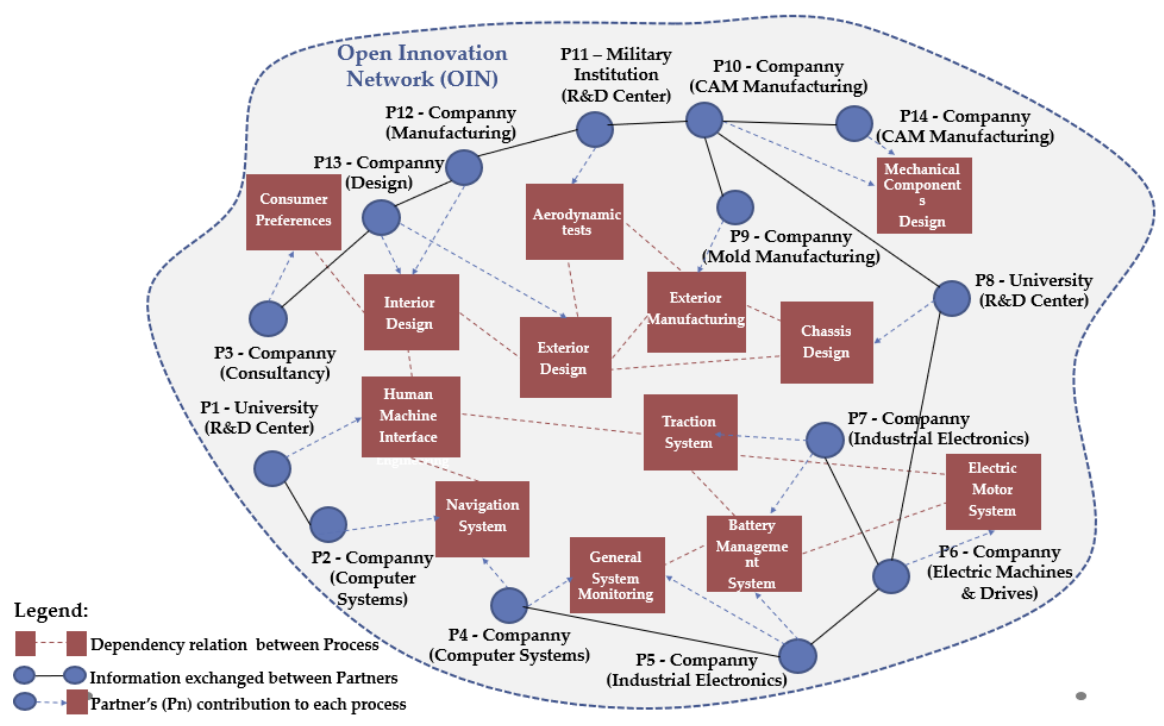

Fig. 4. Diversity of partners and respective competencies involved

It was created 14 partnerships, involved industries from different areas, as well as two R \& D centers (from two Portuguese universities) and a Portuguese military institution) with the aim to develop and test the new components of the car. It was also intended to manufacture a vehicle that would exploit the concept of reverse trike, i.e. a vehicle having 3 wheels on its constitution-base.

The partnerships, established with the two R \& D centers, have consisted on a interdisciplinary involvement of fellow students and other researchers from several areas of engineering (Electrical, Mechanics, Computers and Electronics), where there was an intervention in several disciplinary areas, regarding the vehicle's development (Fig.4).

The existing competences, together with those resulting from the interaction with the different partners, have allowed the development of a set of other competences necessary for the development of the vehicle. 
Still in the scope of the development of the vehicle, there were concerns with the communication abroad, namely with the marketing and sales areas, with all support being assumed by two consulting companies in Marketing and Advertising (Fig.4).

The model application is presented on Table 3.

Table 3. Model application (through Table 1)

\begin{tabular}{|c|c|c|}
\hline Knowledge (K) & $\operatorname{KIn}(\mathbf{n})$ & $\begin{array}{c}\text { Actors } \\
\text { Involved }\end{array}$ \\
\hline K1 & $\begin{array}{l}\text { KI1(1) - Market trends } \\
\text { KI1(6) - Consumer preferences }\end{array}$ & $\begin{array}{l}\text { P5,EC7 } \\
\text { P5, EC7 }\end{array}$ \\
\hline K2 & $\begin{array}{l}\text { KI2(1) - Assembly method } \\
\text { KI2(9) - Innovation management method }\end{array}$ & $\begin{array}{l}\text { P11,EC2 } \\
\text { P4, EC7 }\end{array}$ \\
\hline $\mathbf{K 3}$ & 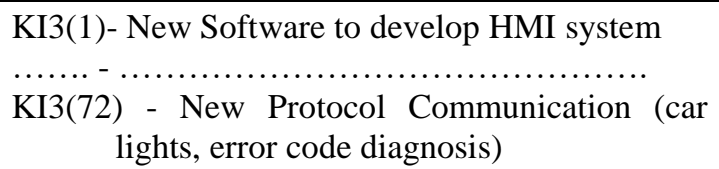 & $\begin{array}{l}\mathrm{P} 2, \mathrm{EC} 10 \\
\ldots \ldots \ldots \\
\mathrm{P} 1, \mathrm{EC} 12\end{array}$ \\
\hline Process $(\operatorname{Pr})$ & $\operatorname{KIn}(\mathbf{n})$ & $\begin{array}{c}\text { Actors } \\
\text { Involved }\end{array}$ \\
\hline Pr1 & $\begin{array}{l}\text { K01Pr1 - Market Annalys (from: K1C1 \& K1C2) } \\
\text { K02Pr1 - Innovation Management (from: K2C2)) } \\
\text { K03Pr1 - Systems Engineering (from: K2C2) }\end{array}$ & $\begin{array}{l}\text { P1,P2,P3 } \\
\text { P11,P13 } \\
\text { P2, P12 }\end{array}$ \\
\hline Pr2 & $\begin{array}{l}\text { K01Pr2 - Traction development system } \\
\text { K02Pr2 - HMI development (from: K3C1) } \\
\ldots \ldots . \ldots \ldots \ldots \ldots \ldots \ldots \ldots \ldots \ldots \\
\text { K87Pr2 - GPS Navigation System }\end{array}$ & $\begin{array}{c}\mathrm{P} 8, \mathrm{P} 7 \\
\mathrm{P} 2, \mathrm{P} 11 \\
\ldots \ldots \\
\mathrm{P} 4\end{array}$ \\
\hline Pr3 & $\begin{array}{l}\text { K01Pr3 - System components design } \\
\text { K02Pr3 - Chassis' design } \\
\ldots \ldots . \ldots \ldots \ldots \ldots \ldots \ldots \ldots . . \\
\text { K23Pr3 - Interior design }\end{array}$ & $\begin{array}{c}\mathrm{P} 5, \mathrm{P} 8 \\
\mathrm{P} 2, \mathrm{P} 5, \mathrm{P} 9 \\
\ldots \ldots \\
\mathrm{P} 1, \mathrm{P} 7\end{array}$ \\
\hline Pr4 & $\begin{array}{l}\text { K01Pr4 - Assembling methods } \\
\text { K02Pr4 - Aerodynamics tests } \\
\ldots \quad-\ldots \ldots \ldots \ldots \ldots \ldots \ldots \\
\text { K34Pr4 - Vehicle performance tests }\end{array}$ & $\begin{array}{c}\mathrm{P} 5, \mathrm{P} 7 \\
\mathrm{P} 2, \mathrm{P} 3 \\
\ldots \ldots \\
\mathrm{P} 9, \mathrm{P} 13\end{array}$ \\
\hline Pr5 & $\begin{array}{l}\text { K01Pr5 - Marketing \&Sales } \\
\text { K02Pr5 - ................... } \\
\text { K12Pr5 - Logistics }\end{array}$ & $\begin{array}{c}\text { P5, P6 } \\
\ldots \ldots \\
\text { P10, P14 }\end{array}$ \\
\hline Interfaces (I) & \multicolumn{2}{|l|}{ Assignment of Innovation Managers } \\
\hline I1 & \multicolumn{2}{|l|}{ P5, P8 } \\
\hline I2 & \multicolumn{2}{|l|}{ P3, P10 } \\
\hline I3 & \multicolumn{2}{|l|}{ P7, P11 } \\
\hline
\end{tabular}

Through Table 3, it can be seen, the relationship between the knowledge transferred and each process group (Prn).

Based on the model proposed before, the partners involved in the project, are presented in Fig.5, as well as the knowledge transfers preformed. 


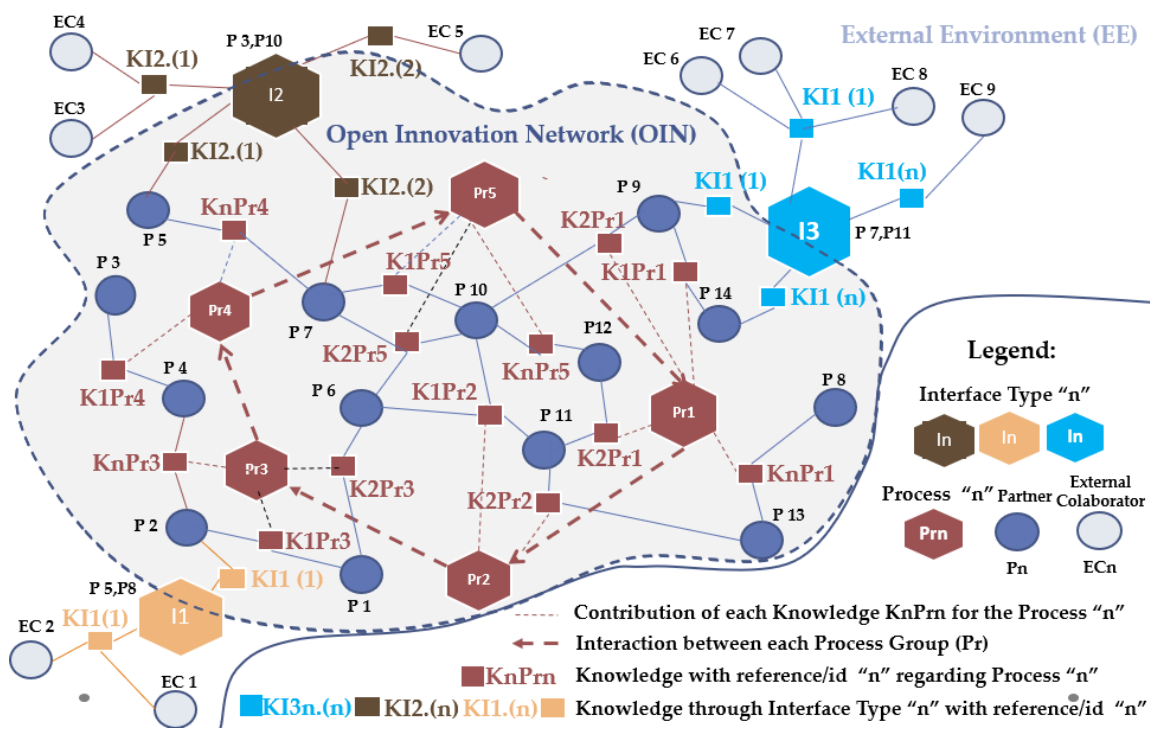

Fig. 5. Model application

The partners (Pn) were also mapped in this methodology, which has helped the innovation managers, regarding I1, I2 and I3, to identify the necessities of in terms of knowledge, associated to each process group (Prn).

The performed tests, regarding the development of the vehicle, have allowed feedback, regarding the components developed by the partner companies, in order to improve them later. One of these tests have involved the aerodynamics of the vehicle, carried out in partnership with a military institution, to optimize the aerodynamic coefficient of the vehicle.

Other tests carried out, was related to the vehicle's battery system, whose performance allowed adjustments in the thermal behavior of the batteries with the load management system developed between the partner companies of the area and the partner universities. These partnerships, have proved to be crucial to the good performance of the vehicle, allowing both companies to gain insight into the development of LiFePO4 (lithium phosphate) batteries for other applications.

\section{Benefits from collaboration}

The benefits of collaboration can be better understood, by presenting 2 scenarios, regarding the development of the electrical vehicle, through the company which have promoted the project, namely; 1, Isolated context and 2, Collaborative context.

On first scenario (isolated context), there is a lack of knowledge, needed by the company as well as other assets, to develop the product, resulting therefore in additional costs, including time. This scenario would delay the development of some specific systems, such as the car battery system for example, which was design specifically for that vehicle, given its specificities. 
Regarding the second scenario (collaborative context), the company had for example, the possibility to learn from the development of the chassis of the car, as well as the other company and the $R \& D$ center involved, which have allowed, to produce new knowledge for both partners, and at the same time, accelerate the chassis process design, given the proximity between both partners, to better discuss the project.

In this sense, and given the knowledge transferred between the different partners of the network, as well as the knowledge transferred from the outside to inside of the network, there was additional competences achieved by all the partners involved, which would be harder, or even impossible in the "isolated context" scenario.

Additionally, and given the proximity between the collaboration partners, the product's time-to-market, was also reduced, regarding the collaboration context, which has allowed the developed product to be more competitive into the segment market of twoseat green passenger vehicles, given the pioneer's strategic advantage.

\section{Conclusions and Further Work}

In this work, it was presented an approach to manage innovation in collaborative context (Open Innovation). A case study was used for its application, by presenting a collaboration network, originally created by a company to produce a green product: an electrical vehicle. The advantages in recurring to Open Innovation, are showed in this work. One of them was cost reduction, regarding the competences, needed to the product developed. Given the collaboration context, the product time-to-market, was also reduced, allowing the company (promoter) to be more competitive in this market segment. The proposal model, proposed and applied in this work, was based on a model existed in literature, although adapted to the collaborative context.

The approach presented here, has allowed to map the partners, involved in this project, as well as the competences needed to develop the final product, by distinguish the competences associated to the internal partners, from the competences associated to the external ones. Based on these last ones, and regarding the collaborative context, it was possible to developed additional competences for every partner of the network.

Given the benefits showed in this work, the approach proposed here, could be applied into other industries, although, and besides the adjustments to be made, there is a need of systematize the external knowledge, i.e., the knowledge group, from the outside of the network, that will be created by the external research, to be applied on network.

\section{Acknowledgments}

This work was partially supported by FCT, through CTS, project UID/EEA/00066/2019.

\section{References}

1. Pisano, G.P.,Verganti, R.: Which Kind of Collaboration Is Right for You? Harvard Business Review. 86, 78-86 (2008) 
2. Camarinha Matos, L. M., Afsarmanesh, H., Abreu, A.: Targeting major new trends. In L. M. Camarinha Matos \& H. Afsarmanesh (Eds.), Collaborative Networked Organizations: A research agenda for emerging business models. Kluwer Academic Publishers (2004).

3. Urze, P., Abreu, A.: System thinking to understand networked innovation. Collaborative Systems for Smart Networked Environments. IFIP AICT. 434, 327-335 (2014).

4. Urze, P., Abreu, A.: Circulation of Knowledge in a Co-innovation Network. In: Collaborative Systems for Reindustrialization; L. M. Camarinha-Matos, Raimar J. Scherer (eds.), pp. 105-112. Springer, Germany (2013)

5. Abreu, A., Camarinha Matos, L. M.: An Approach to Measure Social Capital in Collaborative Networks. In: Adaptation and Value Creating Collaborative Networks; L. M. Camarinha-Matos, Alexandra Pereira-Klen, Hamideh Afsarmanesh (eds.), pp. 29-40. Springer, Germany (2011)

6. Enkel, E., Gassmann, O., Chesbrough, H.: Open R\&D and open innovation: exploring the phenomenon. R\&D Management. 39, 311-316 (2009)

7. Huizingh, E.: Open innovation: State of the art and future perspectives. Technovation. 31, 2-9 (2011)

8. Linstone, H.A.: Comment on "Is open innovation a field of study or a communication barrier to theory development"?. Technovation. 30, 556-556 (2010)

9. Trott, P., Hartmann, D.A.P.: Why Open Innovation is old wine in new bottles International. Journal of Innovation Management. 13, 715-736 (2009)

10. Slowinski, G., Sagal, W.: Good practices in open innovation.Technology Management.53, 38-45 (2010)

11. Chatenier, E., Verstegen, M.A.A.J., Biemans, A.J.H., Mulder, M., Omta, F.W.S.O.: Identification of competencies for professionals in open innovation teams. R\&D Management. 40, $271(2010)$

12. Adler, K.: Social Capital: prospect for a new concept. Academy of Management review. 1740, (2002)

13. Urze, P., Abreu, A. Knowledge Transfer Assessment in a Co-innovation Network. In; Collaborative Networks in the Internet of Services; L. M. Camarinha-Matos, Lai Xu, Hamideh Afsarmanesh (eds.). 561-570. Springer, Germany (2012)

14. Urze, P.; Abreu, A.: Mapping Patterns of Co-innovation Networks. In: Working Conference on Virtual Enterprises. Springer International Publishing, 241-252 (2016)

15. Abreu, A., Urze, P.: System thinking shaping innovation ecosystems. Open Eng.. 6, 418425 (2016)

16. Innocentive, https://www. innocentive.com/

17. Galeano, C. P., Gaviria, P. A.: Open innovation models, a literature review with a focus on SMEs, 2016 11th Iberian Conference on Information Systems and Technologies, pp. 1-13. Las Palmas (2016)

18. Proctor \& Gamble: Connect and Development, https://www.pgconnectdevelop.com/pg-connection-portal/ctx/noauth/PortalHome.do

19. Kline, S.J., Rosenberg, N.: "An overview of innovation." In R. Landau \& N. Rosenberg (eds.), The Positive Sum Strategy: Harnessing Technology for Economic Growth., pp. 275305. National Academy Press, Washington, D.C. (1986)

20. Micaëlli, J.-P., Forest, J., Coatanéa, E..: How to improve Kline and Rosenberg's chainlinked model of innovation: building blocks and diagram-based languages. Journal of Innovation Economics \& Management. 3, 59 - 77.(2014)

21. Forrester, J..: Principles of Systems, Wright Allen. MA, Cambridge (1967),

22. OECD/Eurostat.: Oslo Manual 2018: Guidelines for Collecting, Reporting and Using Data on Innovation, 4th Edition, The Measurement of Scientific, Technological and Innovation Activities, OECD Publishing. Paris/Eurostat, Luxembourg (2018) 